\title{
Investigating the Impact of Firm Characteristics on Capital Structure of Quoted and Unquoted SMEs
}

\author{
Mostafa S. ELbekpashy ${ }^{1} \&$ Khairy ELgiziry ${ }^{2}$ \\ ${ }^{1}$ Group Finance Director, BPE partners (Formerly Beltone Private Equity) \\ ${ }^{2}$ Professor of Finance, Cairo University, Egypt \\ Correspondence: Mostafa S. ELbekpashy, Group Finance Director, BPE partners (Formerly Beltone Private Equity), \\ Egypt
}

Received: November 8, 2017

Accepted: November 29, 2017

Online Published: December 15, 2017

doi:10.5430/afr.v7n1p144

URL: https://doi.org/10.5430/afr.v7n1p144

\begin{abstract}
This study aims to enhance the understanding of SMEs' capital structure in Egypt. The study tests the impact of asset structure (tangibility), size, profitability, liquidity, growth, age, and ownership structure as independent variables on the leverage ratio. Three alternative variables are used as a proxy for leverage: total, long term, and short term leverage. The study further investigates the significance of the relationship between the economic sector as a control variable and the three leverage ratios. Multiple regression analysis is used to develop the explanatory models for two samples of SMEs. The first sample comprises of 28 listed and traded SMEs in Egypt. The second sample includes panel data of 95 non-quoted SMEs. The overall model recommends that all the independent and control variables significantly explain the capital structure decisions of SMEs in Egypt. The results of the analysis of the two samples show a high degree of similarity. The managerial ownership is found to be negatively correlated with short term leverage, while the block holding ownership is positively correlated with the total and the short term leverage. Moreover, the sector shows a significant relationship with the capital structure. The results of the study demonstrate that the financing behavior of SMEs in Egypt is consistent with the pecking order theory. Finally, the study introduces useful recommendations for policy makers and SMEs' management in Egypt.
\end{abstract}

Keywords: Firm Characteristics, Capital Structure, SMEs, Quoted, Unquoted, and Egypt

\section{Introduction}

Since the initial contribution of Modigliani and Miller (M\&M) in 1958, the choice of finance is considered one of the most prominent and prolific areas of research in finance. A significant number of studies centered on this subject have been carried out. Even so, according to Myers (2001), most of the capital structure studies focused on the public corporation. As a result, our understanding of financing choices of other types of companies is still limited. Academic research on the capital structure of SMEs is a recent area of research. Earlier studies that initially emerged were mainly descriptive and focused on developed countries. Consequently, there is a lack of empirical studies discussing the SME's capital structure in developing countries. This study tackles a new research area in a distinction of the classic investigation of large and quoted firms. Studying the capital structure of SMEs is relatively more important in Egypt, given the fact that SMEs are the powerhouse of the Egyptian economy. They are gaining more strength and are supporting the economy to compensate for the declining foreign direct investment (FDI) inflows. The number of SMEs in Egypt reached around 2.5 million enterprises, representing $99 \%$ of the Egyptian non-agriculture private sector companies, employing $75 \%$ of the workforce (EL Said et al., 2014). This article aims to enhance our understanding of the financing behavior of SMEs, noting that SMEs are facing a financing gap in many countries especially in developing countries (OECD, 2006). Radwan and Lotfy (2008) elaborated that Egyptian SMEs are suffering from a financing gap, which primarily consists of supply and knowledge gaps. According to CBE's release of the complete census of SMEs, only $47 \%$ of SMEs are dealing with banks, out of which 22\% have access to debt finance (CBE, 2012; EL Said et al., 2014).

According to Mac an Bhaird (2010), empirical studies suggest that capital structures of SMEs are determined by the firm and owner characteristics. In view of that, the problem statement will be: Exploring and identifying the determinants of capital structure of the Small and Medium Enterprises (SMEs) in Egypt. This study adopts a regression model to analyze a panel data, aiming to test the hypotheses that investigate the following: 
- The impact of a firm's characteristics namely; tangibility, size, liquidity, profitability, age, growth rate, and ownership structure on SMEs' capital structure in Egypt.

- $\quad$ Similarities of financing patterns of quoted and unquoted SMEs in Egypt.

- Which capital structure theory is better at explaining the SMEs' financing decisions in Egypt?

The rest of the study is organized as follows: The following section presents a review of both theoretical and empirical literature of SMEs' capital structure and hypotheses development, then section three presents the methodology used in this research. Thereafter, section four provides details of the results of the descriptive and regression analysis and their interpretation, in comparison with the previous SME studies and the studies which investigated the large listed Egyptian firms. Finally, the study ends with the conclusion, contribution, limitation and implications of the research.

\section{Literature Review and Hypotheses Development}

The researchers introduced in the last decade valuable material that investigates the SMEs' capital structure in some countries such as: Greece (Daskalakis et al., 2014), Australia (Cassar and Holmes, 2003), Spain ( Sogorb-Mira, 2005; Aybar-Arias et al., 2012)), Britain (Zhang, 2010), Netherlands (Degryse et al., 2012), China ( Tian et al., 2015), France, Greece, Portugal and Italy ( Psillaki and Daskalakis, 2009), The UK, Spain, Germany, Ireland, Portugal, Netherlands, and Belgium (Hall et al., 2004), Vietnam (Nguyen and Ramachandran, 2006), Brazil (Forte et al., 2013), Ireland (Mac an Bhaird and Lucey, 2010), Sweden (Yazdanfar and, Ohman (2016), Malaysia (Shahadan and Saarani, 2013), Baltic countries (Krasauskaite and Hirth, 2011), Central and Eastern Europe (Mateev et al., 2013), New Zealand (Hewa Wellalage and Locke , 2015), and Ghana (Bokpin and Arko, 2009).

\subsection{Capital Structure Theories and SMEs Financing}

According to (Sogorb-Mira, 2005), the empirical studies on SMEs revealed that SMEs did not provide a substantial proof to support the trade-off theory. The scholars attributed that to the fact that SMEs face complications in accessing satisfactory debt finance, which hinder their ability to benefit from tax shields. Also, tax effect is not very important for SMEs because small and medium enterprises are less likely to generate very high profits; consequently, they are less likely to benefit from using debt for tax purposes (Pettit and Singer, 1985). According to Holmes and Kent (1991), small and medium enterprises' owner-managers incline to operate without having a targeted optimal capital structure. On the other hand, and as indicated by (Psillaki, 1995), the pecking order theory is more relevant to SMEs as they have high information costs. SMEs with less history used not to favor losing control over their firms which lead them to prefer other options of finance that reduce imposition into their private businesses (Mac an Bhaird and Lucey, 2011).

Regarding the agency theory, there is less conflict between shareholders and managers in SMEs, as SMEs shareholders in many cases are the directors (Ang et al., 2000). The assumption of zero agency cost is also reinforced by Anderson and Reeb (2003). SMEs may face an agency problem if the shareholders and managers are separated. Consequently, it is anticipated that small and medium enterprises pay a higher agency cost, as the process of monitoring small firms is more complicated than large quoted firms (Daskalakis and Psillaki, 2008)

The Life Cycle Theory applies to SMEs, as they are not robust and have high information costs (Psillaki and Daskalakis, 2009), particularly those companies with a fairly short historical presence. Also, Mac an Bhaird and Lucey (2011) presented a study, evidencing that the SMEs are following the life cycle theory in financing their investments. Similarly, OECD (2006) proposed that there is an ascending ladder for financing SMEs which assumed that the sources of financing tend to be evolved according to the firm life cycle. In contrast, according to Gregory et al. (2005), it is not likely to have a single life cycle model for SMEs, as introduced by Berger and Udell (1998).

\subsection{The Impact of Firm Characteristics on SMEs' Capital Structure and Hypotheses Development}

According to Mac an Bhaird (2010), Empirical studies suggest that capital structures of SMEs are determined by the firm and owner characteristics. According to the literature review, the researchers construct the hypotheses (H1:H7) to describe the assumed impact of the relationship of each of the independent variables and the capital structure. Thereafter, the researchers introduce the main hypothesis (H8) to depict the joint impact of the independent variables on the capital structure.

Asset structure (Tangibility): Hall et al. (2004) used a panel data of four thousand SMEs in eight European countries: the UK, Spain, Germany, Ireland, Portugal, Netherlands, and Belgium, to prove that the tangibility has a positive relationship with long-term debt, while it has a negative relationship with the short-term debt. Cassar and Holmes (2003) reached the same conclusion when they investigated a sample of 1,555 Australian SMEs firms. 
Meanwhile, Newman et al. (2013) indicated a negative relationship between leverage and tangibility of the Chinese SMEs. Similarly, Daskalakis and Psillaki (2008) discovered a negative association between the tangibility and the financial leverage, when they examined the factors determining SMEs' capital structure in France and Greece, yet they didn't separate amongst long and short term debt. Conversely, Zhang (2010) inferred that the tangible assets are positively connected to the percentage of debt to equity of SMEs in the British assembling industry. Accordingly, we formulated the following hypothesis:

H1: There is a significant relationship between the firm's asset structure (tangibility) and capital structure of the firm expressed by leverage ratio

Size: Most of the reviewed empirical studies evidenced that the relationship between a company's debt ratio and its size would appear to be positive, such as Psillaki and Daskalakis (2009), who examined the determinants of capital structure of Italian, Greek, French and Portuguese SMEs. There are multiple studies that reached the same conclusion such as Mac an Bhaird and Lucey (2010) who analyzed the capital structure determinants of a sample of 299 Irish SMEs. Similarly, Daskalakis et al. (2014) concluded the same positive relationship of Greek SMEs. Aybar-Arias et al. (2012) concluded the same relationship even between the size and the speed of leverage adjustment of Spanish SMEs. Yazdanfar and Ohman (2016) evidenced the same positive correlation amongst the size and total and short term debt, whereas it had no significant relationship with the long term leverage of the Swedish SMEs. Cassar and Holmes (2003) evidenced a positive relationship between the size of Australian SMEs and long term leverage. However, Benkraiem and Calin (2013) reached the same conclusion regarding the relationship with long term debt, but they concluded a negative relationship between short term leverage and size.

Accordingly, we formulated the following hypothesis:

H2: The firm size has a significant positive relationship with the capital structure of the firm expressed by leverage ratio

Profitability: Daskalakis et al. (2014) tested the capital structure determinants of Greek SMEs, and they concluded a negative relationship between profitability and leverage ratio. They added that the relationship between the two factors was significant only for the short-term leverage. This negative relationship was also confirmed by Cassar and Holmes (2003), and Sogorb-Mira (2005) who investigated Spanish SMEs. Shahadan and Saarani (2013) affirmed the same negative relationship between the profitability and leverage ratio of SMEs, while they investigated the leverage ratio of Malaysian SMEs. Along the same line, Benkraiem and Calin (2013) suggested that the profitability has a negative relationship with all types of leverage, pointing out that the relationship was in its strongest form with the long term leverage of SMEs in France. Many other authors reached the same conclusion such as Hall et al. (2000), but their results showed an insignificant relationship with long term leverage of British unquoted SMEs. At the same time, Nguyen and Ramachandran (2006) proved an insignificant relationship between profitability and leverage of Vietnamese SMEs. Unexpectedly, Zhang (2010) recommended that profitability is positively correlated with the ratio of debt to equity for British manufacturing small and medium enterprises.

Accordingly, we formulated the following hypothesis:

H3: The Profitability has a significant negative relationship with the capital structure of the firm expressed by leverage ratio

Liquidity: Shahadan and Saarani (2013) found that liquidity showed a significant negative relationship with the leverage ratio of Malaysian SMEs. Krasauskaite and Hirth (2011) reached the same conclusion when they tested the leverage decisions of SMEs in the Baltic countries. On the other hand, Mateev et al. (2013) demonstrated that SMEs that keep higher liquidity levels are depending fundamentally on long term debt to finance their growth, whereas the correlation matrix showed a negative relationship between the short term leverage and liquidity. Accordingly, we formulated the following hypothesis:

H4: The liquidity has a significant negative relationship with the capital structure of the firm expressed by leverage ratio.

Growth: Degryse et al. (2012) investigated the influence of the company's characteristics on the capital structure of Dutch SMEs; their results were complying with the pecking order theory. They proved that growing companies increase debt when they require new funds. Therefore, they indicated a positive relationship between growth and long term debt. Many other authors affirmed the same direction of relationship such as Nguyen and Ramachandran (2006), who conducted the same test in Vietnam and Forte et al. (2013), who investigated 19,000 Brazilian SMEs. These studies used the growth of assets or sales as a proxy for growth. Sogorb-Mira (2005) reported a more grounded positive impact of growth on the long term leverage, while Michaelas et al. (1999) found a positive effect on short term leverage. 
Similarly, Cassar and Holmes (2003) proved the positive correlation between growth and all measures of finance, when they tested the SMEs' capital structure in Australia. On the other hand, Hall et al. (2000) concluded the same relationship only with short term debt and no significant relationship with the long-term debt, while THORNHILL et al. (2004) pointed out that the growth seems to have an insignificant relationship with the leverage ratio. Accordingly, we formulated the following hypothesis:

H5: The growth of the firm has a significant positive relationship with the capital structure of the firm expressed by leverage ratio.

Age: The empirical findings presented somewhat contradictory standpoints regarding the relationship between the firm's age and financial leverage. Firms' track records may improve over time making external funding more likely for older firms. On the other hand, firms' retained earnings may increase over time making internal funding more likely for older firms. Therefore, the relationship could be either positive or negative. One of the prominent studies introduced by Hall et al. (2004) concluded that the age has a negative relationship with both short and long term debt in the UK, while SMEs in Spain had an opposite relationship and the results showed an insignificant relationship in the remaining six countries reviewed. The said results advocate that British SMEs depend more on their internal resources through accumulating inside funds.

Yazdanfar and Ohman (2016) claimed that the impact of age of the Swedish SMEs has a significant and negative relationship with both total and short term debt, while it has a positive relationship with long term debt. On the other hand, Tian et al. (2015) suggested that total debt charted a U-shaped pattern in Chinese SMEs, meaning that the leverage ratio decreases until a revival stage inaugurates then it will be increased. Previously, Sanchez-Vidal and Martin-Ugedo (2012) concluded that younger SMEs were utilizing more short term debt than the older when they tested a sample of around 6,000 small and medium firms in Spain. Similarly, Forte et al. (2013) examined the capital structure of more than four thousand SMEs in Brazil, extracted from unbalancing panel data. They confirmed the negative correlation between the leverage and age. Also, they evidenced that the small firms may slowly revisit their capital structure from time to time to adjust, targeting the optimal capital. Aybar-Arias et al. (2012) evidenced the same negative relationship in Spain, but it was weaker and also, the adjustment speed was slow. Despite what might be expected, Romano et al. (2000) tested a sample of privately-owned companies in Australia; their findings highlighted an existence of a positive relationship between age and leverage. Likewise, Vieira (2014) demonstrated the same positive connection between Portuguese privately-owned companies' age and the leverage.

Accordingly, we formulated the following hypothesis:

H6: The firm's age has a significant relationship with the capital structure of the firm expressed by leverage ratio.

Ownership structure: Two recent studies evidenced that the concentrated ownership in China had a negative relationship with the leverage of SMEs (Newman et al., 2013 and Huang et al., 2016). Conversely, other studies indicated a positive relationship (Cheng et al., 2004 and Driffield et al., 2005). Hewa-Wellalage and Locke (2015) found an inverse U-shape relationship between insider ownership and leverage in New Zealand. Also, Brailsford et al. (2002), reached the same conclusion. Accordingly, leverage initially increments with an increase of managerial ownership till a critical level then the leverage ratio will start to decrease as long as the managerial ownership increases. Likewise, Friend and Lang (1988) found that the leverage and managerial ownership were adversely correlated.

On the other hand, Bokpin and Arko (2009) concluded a positive influence of managerial shareholding on long-term debt in Ghana. Similarly, Bajaj et al. (1998) recommended that ownership has a positive relationship with the leverage ratios.

Accordingly, we formulated the following hypothesis:

H7: The ownership of the management and the ownership of the block shareholders have significant relationships with the leverage ratio.

Main Hypotheses: Based on the literature mentioned above and the formulated hypotheses, we constructed the following main and general hypotheses:

H8: The independent variables: tangibility, size, profitability, liquidity, growth, age and ownership structure collectively have a significant impact on the firm's capital structure of the two samples.

H9: SMEs in Egypt are employing short term debt more than long term debt.

H10: The relationships between the capital structure determinants and leverage ratio have the same direction across the two samples of quoted and unquoted SMEs. 
H11: The pecking order theory is better at explaining the capital structure of SMEs.

Control variable: Previous studies indicated that the relationship between firm characteristics and capital structure may vary across the sectors. Therefore, we will control the effect of the economic sector. The most relevant evidence of the effect of industry factor on the relationship between firm characteristics and capital structure introduced by Omran and Pointon (2009). They conducted a cross sectorial study on the capital structure of the listed companies in Egypt. Their conclusion shed light on the significant industry effect. Also, Degryse et al. (2009) reached the same conclusion when they investigated the capital structure of Dutch SMEs, but they attributed the main variation of leverage ratios to firm characteristics, not to industry classification. Similarly, Balakrishnan and Fox (1993) concluded that $11 \%$ of leverage variations are attributed to industry effect, while $52 \%$ is attributed to firm characteristics. Phillips (2005) found that the industry explains 33\% of capital structure deviations. Michaelas et al., (1999) applied industry fixed effects to analyze the impact of industry and they concluded that there is a significant correlation between the leverage and industry dummies; meanwhile, the major significant impact was on short term leverage.

\section{Data and Methodology}

The study tests the capital structure determinants of two samples. The first sample is comprised of records of 28 firms out of total 32 listed SMEs, covering a time horizon from 2008 till 2015. The collected data covers all the years since the first year of trading for each firm till the financial year of 2015. Some of the observations were removed due to the absence of some data or including outliers. The data of the first year of trading for each firm is used as a base year to calculate the growth, and the final sample consisted of 119 observations. In order to unify the data of the two samples, we included only the unquoted SMEs that meet the definition of quoted SMEs (their capital is less than 50 million); also, we classified the firms according to the sectorial classification of the first sample. The second sample (unquoted sample) comprises of 95 firms, covering the period from 2008 till 2015. The sample includes only the SMEs that have records of three consecutive years or more. After excluding the first observation for all firms and outliers, the second sample comprised of 251 observations.

Table 1. Samples' sectors and corporations

\begin{tabular}{|c|c|c|}
\hline \multirow{2}{*}{ Economic Sector } & \multicolumn{2}{|c|}{ Number of Firms } \\
\hline & Quoted & Unquoted \\
\hline Industrial Goods \& Services and Automobiles & 5 & 24 \\
\hline Retail & 4 & 32 \\
\hline Technology and Telecommunication \& Travel & 4 & 1 \\
\hline Construction and Materials \& Real Estate & 6 & 21 \\
\hline Healthcare and Pharmaceuticals \& Chemicals & 5 & 11 \\
\hline Basic Resources \& Food and beverage & 4 & 6 \\
\hline Total & $\mathbf{2 8}$ & 95 \\
\hline
\end{tabular}

Data of the quoted sample has been collected from the Nile Stock Exchange through the companies, which are authorized to disseminate information of the listed companies such as Egyptian Company for Information Dissemination (EGID) and Misr Information Services and Trading (MIST). Regarding the unquoted sample, the data of SMEs has been collected from; private equity funds, that target SMEs and SMEs division in banks. Due to unavailability of data, the second sample does not include the data of the ownership structure and age of the firms.

Regression Model: following Abor (2008) the researchers performed regression analysis to test the impact of the relationships of independent and dependent variables. The researchers analyzed a panel data, as the use of panel data reduces multi-collinearity among the explanatory variables. Thus, improving the efficiency of econometric estimates. Also, that helps in analyzing the change in leverage ratios over periods.

Ordinary Least Square (OLS) method is used, after checking the collinearity, normality, linearity and serial correlations. Based on literature review, the regression models will be as follows: 
TLR $_{i, t}=a+b_{1} A S_{i, t}+b_{2}$ SIZE $_{i, t}+b_{3}$ PROFIT $_{i, t}+b_{4}$ GROWTH $_{i, t}-(t-1)+b_{5}$ LIQUID $_{i, t}+b_{6}$ AGE $_{i, t}$

$+b_{7}$ BLOCK $_{i, t}+b_{8} M^{2} N G_{i, t}+b_{9}$ SECT $_{i, t}+\operatorname{error}_{i, t}$

LTLR $_{i, t}=a+b_{1} A_{S_{i, t}}+b_{2}$ SIZE $_{i, t}+b_{3}$ PROFIT $_{i, t}+b_{4}$ GROWTH $_{i, t}-(t-1)+b_{5}$ LIQUID $_{i, t}+b_{6}$ AGE $_{i, t}$

$+b_{7}$ BLOCK,$t_{i}+b_{8} M A N G_{i, t}+b_{9} S{ }^{2} C T_{i, t}+\operatorname{error}_{i, t}$

STLR $_{i, t}=a+b_{1} A S_{i, t}+b_{2}$ SIZE $_{i, t}+b_{3}$ PROFIT $_{i, t}+b_{4}$ GROWTH $_{, t}-(t-1)+b_{5}$ LIQUID $_{i, t}+b_{6}$ AGE $_{i, t}$

$+b_{7}$ BLOCK,$t+b_{8} M A N G_{i, t}+b_{9} S{ }^{2} C T_{i, t}+$ error $_{i, t}$

Table 2. Variable Identification and Hypothesized Relationships

\begin{tabular}{|c|c|c|c|c|}
\hline Variable & Abbreviation & Type & Meas urement & Hypothesized Relationship \\
\hline $\begin{array}{l}\text { Total Leverage } \\
\text { Ratio }\end{array}$ & TLR & Dependent & $($ Total Debt $/$ Total Assets $) \times 100$ & \\
\hline $\begin{array}{l}\text { Long Term } \\
\text { Leverage Ratio }\end{array}$ & LTLR & Dependent & $($ long term Debt $/$ Total Assets $) \times 100$ & \\
\hline $\begin{array}{l}\text { Short term } \\
\text { Leverage Ratio }\end{array}$ & STLR & Dependent & (short term Debt $/$ Total Assets $) \times 100$ & \\
\hline $\begin{array}{l}\text { Asset Structure } \\
\text { (Tangibility) }\end{array}$ & As & Independent & (Net Fixed Assets/Total Assets $) \times 100$ & $"+/-"$ \\
\hline Size & SIZE & Independent & (Log) Total Assets & + \\
\hline Profitability & PROFIT & Independent & (Net Profit $/$ Total Assets) $\times 100$ & - \\
\hline Liquidity & LIQUID & Independent & (Current Assets /Current Liabilities $) \times 100$ & - \\
\hline Growth & GROWTH & Independent & $\Delta$ Total Sales & + \\
\hline Age & Age & Independent & Number of years since inception & $"+/-"$ \\
\hline $\begin{array}{l}\text { Block Holding } \\
\text { Owners hip }\end{array}$ & BLOCK & Independent & $\begin{array}{l}\text { Ownership percentage of the shareholders } \\
\text { who own more than } 5 \% \text { of company's } \\
\text { shares }\end{array}$ & $"+/-"$ \\
\hline $\begin{array}{l}\text { Managerial } \\
\text { Ownership }\end{array}$ & MANG & Independent & $\begin{array}{l}\text { Ownership percentage of the Board of } \\
\text { Directors }\end{array}$ & $"+/-"$ \\
\hline Sector & SECT & Control & $\begin{array}{l}\text { Dummy variable to indicate firm's } \\
\text { economic sector }\end{array}$ & \\
\hline
\end{tabular}

*Debt include bank debt and other liabilities

\section{Results of the Analysis}

We start our analysis with descriptive analysis

\subsection{Descriptive Analysis}

Table 3. Descriptive statistics of the quoted sample

\begin{tabular}{|c|c|c|c|c|c|c|c|c|c|c|c|}
\hline & $\begin{array}{c}\text { Blockholding } \\
\text { Ownership }\end{array}$ & $\begin{array}{l}\text { Managerial } \\
\text { Ownership }\end{array}$ & $\begin{array}{c}\text { Asset } \\
\text { Structure }\end{array}$ & Size & profitability & Liquidity & Growth & Age & $\begin{array}{c}\text { Total } \\
\text { Leverage } \\
\text { Ratio }\end{array}$ & $\begin{array}{c}\text { Long term } \\
\text { Leverage } \\
\text { Ratio }\end{array}$ & $\begin{array}{c}\text { Short term } \\
\text { Leverage } \\
\text { Ratio }\end{array}$ \\
\hline $\mathrm{N}$ & 119 & 119 & 119 & 119 & 119 & 119 & 119 & 119 & 119 & 119 & 119 \\
\hline Mean & $68.6 \%$ & $57.1 \%$ & $40.1 \%$ & 4.33 & $2.7 \%$ & $616.4 \%$ & $3.6 \%$ & 12.5 & $38.2 \%$ & $9.4 \%$ & $28.8 \%$ \\
\hline Std. Deviation & $22.2 \%$ & $21.8 \%$ & $29.1 \%$ & 0.64 & $7.4 \%$ & $1120.3 \%$ & $34.4 \%$ & 4.8 & $27.0 \%$ & $18.6 \%$ & $22.2 \%$ \\
\hline Minimum & $0.00 \%$ & $10.5 \%$ & $0.10 \%$ & 2.74 & $-29.9 \%$ & $7.6 \%$ & $-92.6 \%$ & 4 & $0.0 \%$ & $0.0 \%$ & $0.0 \%$ \\
\hline Maximum & $100.00 \%$ & $100.00 \%$ & $95.23 \%$ & 6.42 & $19.0 \%$ & $5829.3 \%$ & $102.9 \%$ & 25 & $95.6 \%$ & $81.1 \%$ & $76.4 \%$ \\
\hline
\end{tabular}

Table 4. Descriptive statistics of the unquoted sample

\begin{tabular}{|c|c|c|c|c|c|c|c|c|}
\hline & Asset Structure & Size & profitability & Liquidity & Growth & $\begin{array}{c}\text { Total } \\
\text { Leverage } \\
\text { Ratio }\end{array}$ & $\begin{array}{l}\text { Long term } \\
\text { Leverage } \\
\text { Ratio }\end{array}$ & $\begin{array}{c}\text { Short term } \\
\text { Leverage } \\
\text { Ratio }\end{array}$ \\
\hline $\mathbf{N}$ & 251 & 251 & 251 & 251 & 251 & 251 & 251 & 251 \\
\hline Mean & $31.7 \%$ & 3.99 & $14.4 \%$ & $535.4 \%$ & $20.4 \%$ & $31.4 \%$ & $3.2 \%$ & $28.1 \%$ \\
\hline Std. Deviation & $23.4 \%$ & 0.65 & $14.5 \%$ & $877.6 \%$ & $62.8 \%$ & $20.4 \%$ & $7.5 \%$ & $17.6 \%$ \\
\hline Minimum & $0.0 \%$ & 2.07 & $-13.8 \%$ & $30.9 \%$ & $-99.3 \%$ & $0.1 \%$ & $0.0 \%$ & $0.1 \%$ \\
\hline Maximum & $96.3 \%$ & 5.21 & $90.9 \%$ & $5400.0 \%$ & $583.1 \%$ & $90.0 \%$ & $45.6 \%$ & $70.3 \%$ \\
\hline
\end{tabular}

As indicated by the above tables, the figures of dependent variables show some similarities among the two samples, mainly in short term leverage. The short term leverage in the quoted sample has a mean, maximum, and minimum of $28.8,76.4$, and 0 percentages respectively, which are very similar to the figures of the second sample. The mean, 
maximum, and minimum of the short term leverage in the unquoted sample recorded $28.1,70.1$, and 0 percentages respectively. The long term leverage in both samples was minor compared to the short term leverage and the majority of companies had a $0 \%$ or negligible percentage of long term leverage. Meanwhile, the percentages of long term leverage in the quoted sample are more material. The mean, maximum, and minimum of long term leverage in the quoted sample reached 9.4, 81.1, and 0 percent respectively as opposed to $3.2,45.1$, and 0 percent respectively in the unquoted sample. Consequently, the average of the total leverage of the two samples reached $38.2 \%$ with a maximum of $95.6 \%$ for the quoted sample, and $31.4 \%$ with a maximum of $90 \%$ for the unquoted sample. The minimum total leverage in all firms in both samples recorded $0 \%$. The results mentioned above show similarities to results introduced by Nguyen and Ramachandran (2006), who reported that Vietnamese SMEs had an average leverage ratio of $43.9 \%$.They indicated that short-term liabilities represent a significant proportion of the capital structure, while long-term debts are hardly used by Vietnamese SMEs. Likewise, Shahadan and Saarani (2013), reported an average short term leverage of $42 \%$ out of $53 \%$, representing the average total leverage in Malaysia.

Additionally, the leverage ratios of the Egyptian SMEs were lower than the leverage ratios reported by Hall et al. (2004), who presented average short term leverage ranged between $45 \%$ and $50 \%$ for six European countries with outliers of Italy $63 \%$ and Germany $38 \%$. Also, their results evidenced higher long term debt, ranged from $10 \%$ to $15 \%$ for six countries with outlier Germany of $28 \%$, and the Netherlands of $2 \%$ (the least one). In the same line, the studies of the large listed companies in Egypt confirmed the high contribution of short term leverage, and their ratios were quite similar to Egyptian SMEs. Abobakr and Elgiziry (2015) introduced a recent study, investigating the corporate governance in the large listed companies, and they confirmed the high representation of short term leverage in total leverage. They evidenced that, the average short term leverage reached $31 \%$ which accounted for $72 \%$ of total leverage. Also, El Ansary (2008) evidenced the same average of the short term leverage ratio in his sample which comprised of 61 large listed firms. The study indicated that SMEs in Egypt still didn't consider the concept of using the long term debt to optimize the capital structure and to finance the long term investments. The average long term leverage ratio in quoted and unquoted samples are 9.4\% and 3.2\% respectively as opposed to $12 \%$ in Egyptian large listed firms (Abobakr and Elgiziry, 2015). Similarly, the results of the previous SME studies revealed a higher long term ratios, ranged from $10 \%$ to $15 \%$ in Malaysia, United Kingdom, Belgium, Spain, Ireland, Netherlands, and Portugal (Shahadan and Saarani, 2013 and Hall et al., 2004). Finally, Egyptian SMEs showed average total leverage ratios lower than SMEs in China, which reached $54 \%$ as reported by Newman et al. (2013).

The average of block holding ownership of the quoted sample was $68.6 \%$, ranging from $0 \%$ to $100 \%$, which indicates a high degree of ownership concentration. In addition to ownership concentration, the descriptive analysis shows that the management of SMEs in Egypt owns the majority of their firms. The average ratio of managerial ownership reached $57.1 \%$, ranging from $10 \%$ to $100 \%$. Therefore, we conclude that the ownership of the quoted SMEs in Egypt is not fragmented and there are major shareholders in most of the firms, and they are controlling and managing their businesses.

The results of SMEs in Egypt are quite similar to SMEs in China, as reported by a Newman et al. (2013). He pointed out that a significant proportion of Chinese private SMEs is under the control of a single owner, who is typically the founder of the business. Similarly, Abobakr and Elgiziry (2015) highlighted that the ownership of large Egyptian firms is not fragmented, the average block holding ownership contributed to $43.8 \%$ of the total firms' ownership. Also, the high average ratio of managerial ownership is consistent with the average SMEs' managerial ownership in New Zealand as reported by Hewa Wellalage and Locke (2015). Also, they highlighted that $43 \%$ of their tested firms have insider ownership ranging between $25 \%-50 \%$, while $12 \%$ of the sample had insider ownership more than $75 \%$. Abor (2008) resulted in a managerial ownership of $80 \%$ of SMEs in Ghana and recommended a negative correlation between managerial ownership and leverage ratio

The asset structure of SMEs in both samples showed quite similar ratios. The average asset structure in quoted sample reached $40 \%$ as opposed to $31.7 \%$ in the unquoted sample, ranging from $0 \%$ to $95 \%$ and $96 \%$ in both samples. The firms with extreme tangible assets are in a dangerous financial position, as the high tangibility ratio may lead to a liquidity problem. Meanwhile, the firms with very low tangibility may face obstacles to find long-term finance. Also, the average size of both quoted and unquoted SMEs was very similar, which may be attributed to using same criteria in selecting the two samples.

Newman et al. (2013) and Shahadan \& Saarani (2013) reported very similar tangibility ratios of 35\% in China and Malaysia. However, they reported a bigger average size than the average of SMEs in Egypt, the LOG size of their samples reached 10.1 and 7.4 respectively, while the average LOG size of Egyptian SMEs reached 4.3 and 3.99 for quoted and unquoted Egyptian SMEs. 
In contrast to the size and asset structure, the profitability ratios in the two samples were different. The average profitability of the quoted SMEs was $2.7 \%$, ranging from $-29.9 \%$ to $19 \%$ as opposed to the average profitability of $14.4 \%$ in the unquoted sample, ranging from $-13.8 \%$ to $90.9 \%$, that means the unquoted SMEs were generating more profits during that period. The figures of the firms in both quoted and unquoted samples indicate a very high liquidity ratio. The growth ratios of the two samples show high variations, the average growth ratio of the quoted sample was meager of $3.6 \%$, ranging from $-92.6 \%$ to $102.9 \%$. The average growth of the unquoted sample reached $20.4 \%$, ranging from $-99.3 \%$ to $583.1 \%$. The average age of the quoted sample was 12.5 years, ranging from 4 to 25 years. Therefore, the majority of listed SMEs in Egypt couldn't be considered old firms and they still didn't achieve a high growth rate. The results of Shahadan and Saarani (2013), in Malaysia, showed some similarities with the results of quoted SMEs in Egypt, in terms of high average liquidity of 195\%, low average growth of 3.3\%, and average age of 19.9 years

\subsection{Pearson's Correlation between Dependent and Independent Variables}

The correlation matrix is generated and the results show no sign of multi-collinearity among the independent variables (table 5\&6). As further verification, the tolerance and variable inflation factor (VIF) are examined. Based on Hair et al. (2006), the VIF should be less than 10 and tolerance between 0.1 and 1 , as an indication of no multi-collinearity. The VIF values of the independent variables of the first sample ranged from 1.08 to 2.37 and ranged from 1.07 to 2.82 in the second sample. The tolerance values of all independent variables were more than 0.1 and less than 1 in the two samples. The said results confirm the absence of the multi-collinearity problem.

Table 5. Pearson Correlation for the Quoted Sample

\begin{tabular}{|c|c|c|c|c|c|c|c|c|c|c|c|c|c|c|c|c|c|}
\hline & $\begin{array}{c}\text { Total } \\
\text { Leverage } \\
\text { Ratio } \\
\end{array}$ & $\begin{array}{c}\text { Long term } \\
\text { Leverage } \\
\text { Ratio } \\
\end{array}$ & $\begin{array}{c}\text { Short term } \\
\text { Leverage } \\
\text { Ratio } \\
\end{array}$ & $\begin{array}{c}\text { Blockholding } \\
\text { Ownership }\end{array}$ & $\begin{array}{c}\text { Managerial } \\
\text { Ownership }\end{array}$ & $\begin{array}{c}\text { Asset } \\
\text { Structure }\end{array}$ & Size & profitability & Liquidity & Growth & Age & $\begin{array}{c}\text { Industrial } \\
\text { Sector }\end{array}$ & $\begin{array}{l}\text { Retail } \\
\text { Sector }\end{array}$ & $\begin{array}{c}\text { Technology \& } \\
\text { Travel Sector }\end{array}$ & $\begin{array}{l}\text { Construction } \\
\text { Sector }\end{array}$ & $\begin{array}{c}\text { Health } \\
\text { \&Pharma } \\
\text { Sector } \\
\end{array}$ & $\begin{array}{c}\text { Basic } \\
\text { Resources\& } \\
\text { Food Sector } \\
\end{array}$ \\
\hline $\begin{array}{l}\text { Total } \\
\text { Leverage Ratio }\end{array}$ & 1 & $.576^{10}$ & $.731^{* *}$ & 0.169 & -0.006 & $-288-^{* *}$ & $.537^{* 8}$ & -0.163 & $. .502-"$ & 0.008 & $.236^{* *}$ & -0.177 & -.218 - $^{*}$ & $.246^{* *}$ & $.253^{* *}$ & $.226^{\circ}$ & $-.337 .^{* *}$ \\
\hline $\begin{array}{l}\text { Long term } \\
\text { Leverage Ratio }\end{array}$ & $.576^{* *}$ & 1 & -0.137 & $.224^{*}$ & $.263^{* *}$ & -0.055 & $.376^{* 06}$ & -189." & -0.117 & -0.006 & 0.028 & $-.201-^{*}$ & $-.1900^{*}$ & 0.030 & $.653^{* *}$ & $-.1833^{\circ}$ & -0.141 \\
\hline $\begin{array}{l}\text { Short term } \\
\text { Leverage Ratio }\end{array}$ & $.7311^{* *}$ & -0.137 & 1 & 0.018 & $-.2260^{*}$ & $-.303-^{* *}$ & $.336^{\prime \prime \prime}$ & -0.040 & $-.511-^{* "}$ & 0.015 & $.263^{* *}$ & -0.046 & -0.105 & $.273^{* *}$ & $-.239-^{* * *}$ & $.427^{* *}$ & $-.291-^{* *}$ \\
\hline $\begin{array}{l}\text { Blockholding } \\
\text { Ownership }\end{array}$ & 0.169 & $.224^{*}$ & 0.018 & 1 & $.626^{* *}$ & -0.165 & $.271^{\prime \prime \prime}$ & $.222^{\circ}$ & 0.072 & 0.026 & $.525^{* *}$ & -0.009 & -.187 ." $^{*}$ & $-.2533^{* *}$ & $.223^{*}$ & 0.008 & 0.128 \\
\hline $\begin{array}{l}\text { Mangerial } \\
\text { Ownership }\end{array}$ & -0.006 & $.263^{* 18}$ & $-.2266^{*}$ & $.626^{* *}$ & 1 & -0.057 & 0.072 & 0.172 & 0.094 & -0.031 & $.320^{* *}$ & 0.129 & -0.123 & -0.038 & $.304^{* *}$ & $-.335 .^{* *}$ & 0.059 \\
\hline $\begin{array}{l}\text { Asset } \\
\text { Structure }\end{array}$ & $-.288-^{* k}$ & -0.055 & $-.303-^{3 * *}$ & -0.165 & -0.057 & 1 & $-.338-^{* *}$ & -0.156 & -0.063 & 0.045 & -0.159 & 0.048 & $.271^{* *}$ & 0.010 & -0.063 & $-298-^{* *}$ & 0.098 \\
\hline Size & $.537^{* * 4}$ & $.376^{* *}$ & $.336^{* * *}$ & $.271^{* * *}$ & 0.072 & $-.338-^{* *}$ & 1 & 0.157 & $-2500^{* " *}$ & 0.103 & $.253^{* * *}$ & $-.190-^{*}$ & -0.076 & -0.161 & $.352^{* * *}$ & $.230^{\circ}$ & $-.249-^{* *}$ \\
\hline profitability & -0.163 & $-.189 . "$ & -0.040 & $.222^{*}$ & 0.172 & -0.156 & 0.157 & 1 & 0.128 & 0.161 & 0.177 & 0.098 & 0.030 & $-.191 . "$ & -0.144 & $.284^{* *}$ & -0.142 \\
\hline Liquidity & $-.502-^{* *}$ & -0.117 & $-.5111^{* *}$ & 0.072 & 0.094 & -0.063 & $-.2500^{6 " s}$ & 0.128 & 1 & -0.047 & $-.1866^{*}$ & -0.048 & 0.065 & -0.131 & -0.062 & $-2033^{\circ}$ & $.386^{* *}$ \\
\hline Growth & 0.008 & -0.006 & 0.015 & 0.026 & -0.031 & 0.045 & 0.103 & 0.161 & -0.047 & 1 & 0.045 & 0.014 & -0.024 & -0.050 & -0.121 & 0.150 & 0.008 \\
\hline Age & $.236^{* *}$ & 0.028 & $.263^{* *}$ & $.525^{* *}$ & $.320^{* *}$ & -0.159 & $.253^{\circ "}$ & 0.177 & $-.186-^{*}$ & 0.045 & 1 & 0.066 & -0.167 & $-.2711^{* *}$ & -0.009 & $.267^{* * *}$ & 0.005 \\
\hline $\begin{array}{l}\text { Industrial } \\
\text { Sector }\end{array}$ & -0.177 & $.2011^{*}$ & -0.046 & -0.009 & 0.129 & 0.048 & $-.1900^{*}$ & 0.098 & -0.048 & 0.014 & 0.066 & 1 & $-.1822^{*}$ & -0.148 & $-.2333^{*}$ & $-.251-^{* *}$ & $.208{ }^{*}$ \\
\hline Retail Sector & $-.218-^{*}$ & $-.190-^{*}$ & -0.105 & $-.187 .^{*}$ & -0.123 & $.271^{* 18}$ & -0.076 & 0.030 & 0.065 & -0.024 & -0.167 & $-.182-^{*}$ & 1 & -0.126 & $-.198 .^{*}$ & $.2144^{\circ}$ & -0.177 \\
\hline $\begin{array}{l}\text { Technology \& } \\
\text { Travel Sector }\end{array}$ & $.246^{* * 4}$ & 0.030 & $.273^{* * *}$ & $-.253-^{* *}$ & -0.038 & 0.010 & -0.161 & $-.1911^{*}$ & -0.131 & -0.050 & $-.2711^{* "}$ & -0.148 & -0.126 & 1 & -0.160 & -0.173 & -0.143 \\
\hline $\begin{array}{l}\text { Construction } \\
\text { Sector }\end{array}$ & $.253^{* t+}$ & $.653^{* 3}$ & $-239 .^{-* *}$ & $.223^{*}$ & $.304^{* *}$ & -0.063 & $.352^{s 8}$ & -0.144 & -0.062 & -0.121 & -0.009 & $-.233-^{*}$ & -.198*" & -0.160 & 1 & $.272 .^{* * *}$ & $-.226{ }^{*}$ \\
\hline $\begin{array}{l}\text { Health } \\
\text { \&Pharma } \\
\text { Sector }\end{array}$ & $.226^{*}$ & $-.1833^{*}$ & $.427^{* * *}$ & 0.008 & $-335{ }^{* * *}$ & $-298 *^{* *}$ & $.230^{*}$ & $.284^{* *}$ & $-203-^{*}$ & 0.150 & $.267^{* * *}$ & $-.2511^{* * *}$ & -214 - $^{*}$ & -0.173 & $-.272-^{* *}$ & 1 & $-.243-^{* *}$ \\
\hline $\begin{array}{l}\text { Basic } \\
\text { Resources\& } \\
\text { Food Sector }\end{array}$ & $-.337 .^{* *}$ & -0.141 & $-.291-^{* *}$ & 0.128 & 0.059 & 0.098 & $-249 . " 1$ & -0.142 & $.386^{6 *}$ & 0.008 & 0.005 & $-.208{ }^{*}$ & -0.177 & -0.143 & -.226 - $^{\prime \prime}$ & $-.243-^{* *}$ & 1 \\
\hline
\end{tabular}

The above table shows that the total leverage had significant negative correlations with the asset structure and liquidity, while it had significant positive correlations with size and age at the level of 0.01 . Long term leverage had a significant negative correlation with profitability at the level of 0.05 , while it had significant positive correlations with size, managerial ownership, and block holding ownership at the level of $0.01,0.01$, and 0.05 respectively. Short 
term leverage had significant negative correlations with the asset structure, liquidity, and managerial ownership at the level of $0.01,0.01$, and 0.05 respectively, while it had significant positive correlations with size and age at the level of 0.01.The results show that all leverage ratios have significant correlation with the control variable (sector)

Block holding ownership had significant positive correlations with managerial ownership, size, age, and profitability. SMEs with concentrated ownership tends to be older, larger, and more profitable and managed by their owners. Similarly, Managerial ownership had a significant positive correlation with age at the level of .01, which indicates that the older SMEs are managed by their owners. Asset structure had a significant negative correlation with size at the level of .01. Meanwhile, the size had a significant negative correlation with liquidity and a significant positive correlation with age at the level of 0.01 . Liquidity had a significant negative correlation with age at the level of 0.05 , while growth had no significant correlation with any of independent variables or control variable.

Table 6. Pearson Correlation for the Unquoted Sample

\begin{tabular}{|c|c|c|c|c|c|c|c|c|c|c|c|c|c|c|}
\hline & $\begin{array}{c}\text { Total } \\
\text { Leverage } \\
\text { Ratio }\end{array}$ & $\begin{array}{c}\text { Long term } \\
\text { Leverage } \\
\text { Ratio }\end{array}$ & $\begin{array}{c}\text { Short term } \\
\text { Leverage } \\
\text { Ratio }\end{array}$ & $\begin{array}{c}\text { Asset } \\
\text { Structure }\end{array}$ & Size & Profitability & Liquidity & Growth & $\begin{array}{l}\text { Industrial } \\
\text { Sector }\end{array}$ & $\begin{array}{l}\text { Retail } \\
\text { Sector }\end{array}$ & $\begin{array}{c}\text { Technology } \\
\text { \& Travel } \\
\text { Sector }\end{array}$ & $\begin{array}{l}\text { Construction } \\
\text { Sector }\end{array}$ & $\begin{array}{c}\text { Health \& } \\
\text { Pharma } \\
\text { sector }\end{array}$ & $\begin{array}{c}\text { Basic } \\
\text { Resources \& } \\
\text { Food Sector }\end{array}$ \\
\hline Total Leverage Ratio & 1 & $.524^{* *}$ & $.933^{* *}$ & -.052 & $.443^{* * *}$ & $-.282^{* * *}$ & $-.545^{* * *}$ & .105 & $.337^{* * *}$ & -.093 & -.048 & $-.400^{* * *}$ & $.142^{*}$ & .115 \\
\hline $\begin{array}{l}\text { Long term Leverage } \\
\text { Ratio }\end{array}$ & $.524^{* * *}$ & 1 & $.181^{* * *}$ & $.174^{* * *}$ & $.375^{* * *}$ & $-.188^{* * *}$ & $-.163^{* * *}$ & -.106 & $.241^{* *}$ & $-.164^{* *}$ & .023 & $-.170^{* * *}$ & .091 & .101 \\
\hline $\begin{array}{l}\text { Short term Leverage } \\
\text { Ratio }\end{array}$ & $.933^{* * *}$ & $.181^{* *}$ & 1 & $-.134^{*}$ & $.352^{* *}$ & $-.246^{* * *}$ & $-.560^{* * *}$ & $.166^{* *}$ & $.286^{* *}$ & -.038 & -.065 & $-.390^{* * *}$ & $.126^{*}$ & .090 \\
\hline Asset Structure & -.052 & $.174^{* * *}$ & $-.134^{*}$ & 1 & $.311^{* * *}$ & .012 & .053 & -.020 & .010 & $-.281^{* *}$ & .097 & -.050 & $.353^{* * *}$ & .070 \\
\hline Size & $.443^{* *}$ & $.375^{* * *}$ & $.352^{* *}$ & $.311^{* * *}$ & 1 & $-.221^{* *}$ & $-.308^{* * *}$ & -.040 & $.235^{* *}$ & $-.231^{* * *}$ & -.080 & $-.370^{* * *}$ & $.300^{* * *}$ & $.249^{* * *}$ \\
\hline Profitability & $-.282^{* *}$ & $-.188^{* * *}$ & $-.246^{* *}$ & .012 & $-.221^{* *}$ & 1 & $.235^{* *}$ & $.208^{* * *}$ & -.044 & -.080 & -.076 & $.183^{* * *}$ & -.117 & .094 \\
\hline Liquidity & $-.545^{* *}$ & $-.163^{* *}$ & $-.560^{* * *}$ & .053 & $-.308^{* * *}$ & $.235^{* *}$ & 1 & .041 & -.109 & -.042 & -.031 & $.389^{* * *}$ & $-.169^{* *}$ & -.099 \\
\hline Growth & .105 & -.106 & $.166^{* *}$ & -.020 & -.040 & $.208^{* *}$ & .041 & 1 & .026 & $-.131^{*}$ & -.042 & $.136^{*}$ & .017 & -.022 \\
\hline Industrial Sector & $.337^{* * *}$ & $.241^{* *}$ & $.286^{* *}$ & .010 & $.235^{* *}$ & -.044 & -.109 & .026 & 1 & $-.430^{* * *}$ & -.056 & $-.298^{* * *}$ & $-.249^{* *}$ & -.094 \\
\hline Retail Sector & -.093 & $-.164^{* *}$ & -.038 & $-.281^{* *}$ & $-.231^{* *}$ & -.080 & -.042 & $-.131^{*}$ & $-.430^{* * *}$ & 1 & -.061 & $-.324^{* * *}$ & $-.271^{* *}$ & $-.207^{* * *}$ \\
\hline $\begin{array}{l}\text { Technology\& Travel } \\
\text { Sector }\end{array}$ & -.048 & .023 & -.065 & .097 & -.080 & -.076 & -.031 & -.042 & -.056 & -.061 & 1 & -.042 & -.035 & -.027 \\
\hline Construction Sector & $-.400^{* * *}$ & $-.170^{* * *}$ & $-.390^{* * *}$ & -.050 & $-.370^{* * *}$ & $.183^{* *}$ & $.389^{* * *}$ & $.136^{*}$ & $-.298^{* * *}$ & $-.324^{* *}$ & -.042 & 1 & $-.188^{* * *}$ & $-.143^{*}$ \\
\hline $\begin{array}{l}\text { Health \& Pharma } \\
\text { sector }\end{array}$ & $.142^{*}$ & .091 & $.126^{*}$ & $.353^{* *}$ & $.300^{* * *}$ & -.117 & $-.169^{* * *}$ & .017 & $-.249^{* * *}$ & $-.271^{* *}$ & -.035 & $-.188^{* * *}$ & 1 & -.120 \\
\hline $\begin{array}{l}\text { Basic Resources \& } \\
\text { Food Sector }\end{array}$ & .115 & .101 & .090 & .070 & $.249^{* *}$ & .094 & -.099 & -.022 & -.094 & $-.207^{* * *}$ & -.027 & $-.143^{*}$ & -.120 & 1 \\
\hline
\end{tabular}

The above table shows that the total leverage had significant negative correlations with the profitability and liquidity, while it had a significant positive correlation with size at the level of 0.01 . Long term leverage had significant negative correlations with profitability and liquidity at the level of 0.01 , while it had significant positive correlations with size and asset structure at the level of 0.01 . Short term leverage had significant negative correlations with the asset structure, liquidity, and profitability at the level of $0.05,0.01$, and 0.01 respectively, while it had significant positive correlations with size and growth at the level of 0.01 . The three leverage ratios showed significant correlation with the control variable (sector). Asset structure had a significant positive correlation with size at the level of 0.01 . Meanwhile, size had significant negative correlations with liquidity and profitability at the level of 0.01. Profitability had positive correlations with liquidity, growth, and construction sector.

\subsection{Results of Hypotheses Testing}

We applied regression analysis to panel data collected from the two samples separately, using OLS method to test the hypotheses. The researchers performed the analysis through the Statistical Package for Social Science (SPSS) version 23 . The researchers performed some tests to ensure the quality of data and models.

Prior to performing the regression analysis, we tested the normality and linearity of residuals of all the six models through Histogram, P-P plot and Q-Q plot analysis, all of them show normality and linearity. The second model of each sample, which tests the impact of firm characteristics on the long term showed the lowest degree of linearity. As a robustness check, the researchers performed Shapiro-Wilk and Kolmogorov-Smirnov tests to ensure the normality. The results of the said tests ensured the normality of the total leverage and short term leverage models of the two samples. The significance of tests results were more than 0.05 , which indicates normality. The results of Shapiro-Wilk and Kolmogorov-Smirnov for the total leverage model and short term leverage model of the quoted sample were as follows $0.22,0.07,0.081$, and 0.091 respectively. For the second sample, we depended more on results of Kolmogorov-Smirnov, as the sample is large (more than 200); both results of the total leverage and short term leverage models recorded 0.2. Also, the normality is ensured through using the large samples. Finally, the 
researchers tested the serial correlation through Durbin-Watson test. The results revealed that Durbin-Watson values ranged from 1.4 to 1.9 for the first sample, and ranged from 2.005 to 2.25 for the second sample, the Durbin-Watson test evidenced the absence of residuals serial correlation problem.

Table 7. Multiple regression analysis of quoted sample

\begin{tabular}{|c|c|c|c|c|c|c|c|c|c|}
\hline & \multicolumn{3}{|c|}{ Total Leverage Ratio } & \multicolumn{3}{|c|}{ Long-Term Leverage Ratio } & \multicolumn{3}{|c|}{ Short-Term Leverage Ratio } \\
\hline & $\mathbf{B}$ & $\mathbf{t}$ & sig & $\mathbf{B}$ & $\mathbf{t}$ & sig & $\mathbf{B}$ & $\mathbf{t}$ & sig \\
\hline (Constant) & -27.314 & -1.693 & 0.093 & -30.214 & -2.376 & 0.019 & 2.912 & 0.222 & 0.825 \\
\hline $\begin{array}{l}\text { Blockholding } \\
\text { Ownership }\end{array}$ & 0.247 & 2.203 & o.030 & 0.062 & 0.705 & 0.483 & 0.184 & 2.026 & 0.045 \\
\hline $\begin{array}{l}\text { Mangerial } \\
\text { Ownership }\end{array}$ & -0.159 & -1.392 & 0.167 & 0.067 & 0.751 & 0.454 & -0.226 & -2.439 & 0.016 \\
\hline Asset Structure & -0.119 & -1.832 & 0.070 & 0.031 & 0.607 & 0.545 & -0.151 & -2.841 & 0.005 \\
\hline Size & 14.534 & 4.395 & 0.000 & 6.281 & 2.409 & 0.018 & 8.250 & 3.068 & 0.003 \\
\hline profitability & -0.737 & -2.842 & 0.005 & -0.360 & -1.764 & $\mathbf{0 . 0 8 1}$ & -0.376 & -1.786 & 0.077 \\
\hline Liquidity & -0.007 & -3.753 & о.000 & 0.000 & -0.066 & 0.947 & -0.007 & -4.551 & o.ooo \\
\hline Growth & 0.001 & 0.021 & 0.983 & 0.035 & 0.906 & 0.367 & -0.034 & -0.854 & 0.395 \\
\hline Age & 0.598 & 1.349 & 0.180 & -0.104 & -0.296 & 0.768 & 0.702 & 1.946 & 0.054 \\
\hline Industrial Sector & -6.959 & -1.169 & 0.245 & -1.031 & -0.220 & 0.827 & -5.932 & -1.226 & 0.223 \\
\hline Retail Sector & -8.155 & -1.241 & 0.217 & -2.340 & -0.452 & 0.652 & -5.816 & -1.088 & 0.279 \\
\hline $\begin{array}{l}\text { Technology \& Travel } \\
\text { Sector }\end{array}$ & 23.665 & 3.073 & 0.003 & 8.370 & 1.379 & 0.171 & 15.290 & 2.442 & 0.016 \\
\hline Construction Sector & 2.040 & 0.312 & 0.756 & 24.640 & 4.773 & O.000 & -22.603 & -4.245 & 0.000 \\
\hline $\begin{array}{l}\text { Basic Resources \& } \\
\text { Food Sector }\end{array}$ & -12.626 & -1.898 & 0.060 & 0.132 & 0.025 & 0.980 & -12.756 & -2.359 & 0.020 \\
\hline \multicolumn{10}{|c|}{ Goodness of Fit Statistics } \\
\hline $\mathbf{R}$ & & 0.789 & & & 0.712 & & & 0.796 & \\
\hline R Square & & 0.623 & & & 0.507 & & & 0.634 & \\
\hline Adjusted R Square & & 0.576 & & & 0.446 & & & 0.589 & \\
\hline Durbin-Wats on & & 1.707 & & & 1.937 & & & 1.417 & \\
\hline $\mathbf{F}$ & & 13.353 & & & 8.307 & & & 13.994 & \\
\hline Sig. F Change & & 0.000 & & & o.ooo & & & O.000 & \\
\hline
\end{tabular}

Table 8. Multiple regression analysis of unquoted sample

\begin{tabular}{|c|c|c|c|c|c|c|c|c|c|}
\hline \multicolumn{10}{|c|}{ Coefficient Of Multiple Regression } \\
\hline & \multicolumn{3}{|c|}{ Total Leverage Ratio } & \multicolumn{3}{|c|}{ Long-Term Leverage Ratio } & \multicolumn{3}{|c|}{ Short-Term Leverage Ratio } \\
\hline & B & $\mathrm{t}$ & sig & B & $\mathrm{t}$ & sig & B & $\mathrm{t}$ & sig \\
\hline (Constant) & 12.072 & 1.422 & $\mathbf{0 . 1 5 6}$ & -10.873 & -2.781 & $\mathbf{0 . 0 0 6}$ & 22.945 & 3.094 & $\mathbf{0 . 0 0 2}$ \\
\hline Asset Structure & -0.101 & -2.194 & 0.029 & 0.030 & 1.413 & 0.159 & -0.131 & -3.257 & 0.001 \\
\hline Size & 7.102 & 3.845 & $\mathbf{0 . 0 0 0}$ & 3.176 & 3.734 & $\mathbf{0 . 0 0 0}$ & 3.927 & 2.434 & 0.016 \\
\hline profitability & -0.219 & -3.111 & 0.002 & -0.054 & -1.659 & 0.098 & -0.166 & -2.688 & 0.008 \\
\hline Liquidity & -0.009 & -7.024 & 0.000 & 0.000 & -0.781 & 0.436 & -0.008 & -7.631 & 0.000 \\
\hline Growth & 0.054 & 3.478 & 0.001 & -0.009 & -1.277 & 0.203 & 0.063 & 4.656 & o.000 \\
\hline Indus trial Sector & 8.235 & 2.668 & 0.008 & 3.578 & 2.518 & 0.012 & 4.657 & 1.728 & 0.085 \\
\hline Retail Sector & -1.556 & -0.461 & 0.645 & 0.645 & 0.415 & 0.679 & -2.201 & -0.746 & 0.456 \\
\hline $\begin{array}{l}\text { Technology \& Travel } \\
\text { Sector }\end{array}$ & -6.995 & -0.636 & 0.525 & 3.654 & 0.722 & 0.471 & -10.649 & -1.108 & 0.269 \\
\hline Cons truction Sector & -6.590 & -1.692 & 0.092 & 1.471 & 0.820 & 0.413 & -8.061 & -2.369 & 0.019 \\
\hline $\begin{array}{l}\text { Basic Resources and } \\
\text { Food Sector }\end{array}$ & 2.849 & 0.716 & 0.475 & 1.859 & 1.015 & 0.311 & 0.990 & 0.285 & 0.776 \\
\hline \multicolumn{10}{|c|}{ Goodness of Fit Statistics } \\
\hline $\mathbf{R}$ & & 0.700 & & & 444 & & & 0.694 & \\
\hline R Square & & 0.490 & & & 197 & & & 0.482 & \\
\hline Adjus ted R Square & & 0.469 & & & 164 & & & 0.460 & \\
\hline Durbin-Wats on & & 2.090 & & & 252 & & & 2.005 & \\
\hline $\mathbf{F}$ & & 23.081 & & & 892 & & & 22.309 & \\
\hline Sig. F Change & & 0.000 & & & о00 & & & $\mathbf{0 . 0 0 0}$ & \\
\hline
\end{tabular}

\subsubsection{Asset Structure (Tangibility) and Leverage Ratio}

The regression results indicated that there are significant negative relationships between the tangibility and total leverage \& short term leverage in the quoted sample at the level of 0.10 and 0.01 respectively. Similarly, the same results are shown in the unquoted sample at the level of 0.05 and 0.01 for both of total and short term leverage, respectively. Conversely, the tangibility was positively insignificant to long term leverage in both samples. Therefore, we partially accept the hypothesis number 1, which states that: There is a significant relationship between the firm's tangibility and capital structure of the firm expressed by leverage ratio. Similarly, this relationship was demonstrated by previous SME studies such as Hall et al. (2004) and Cassar and Holmes (2003). The previous literature of the 
large Egyptian companies reached a quite similar conclusion (Omran and Pointon, 2009). These past reviews demonstrated a positive relationship between utilization of Long-term liabilities and tangibility, recommending that the tangible asset is the important determinant of access to outside fund for SMEs. These findings revealed a negative association between short range debt and tangible assets, proposing that organizations' short term range liabilities are secured by other short-tenure guarantees, or could be uncovered liability.

\subsubsection{Size and Leverage Ratio}

The hypothesis number 2, which states that: The firm size has a significant positive relationship with the capital structure of the firm expressed by leverage ratio, is confirmed by the results of both samples. The average size of the two samples was similar, and moreover, it showed a perfect compatible positive relationship with the three leverage ratios in quoted and unquoted samples. The previous literature of both SMEs and large Egyptian firms showed the same positivity, but it wasn't significant with all leverage ratios (Mac an Bhaird and Lucey, 2010; Daskalakis et al.2014; Omran and Pointon, 2009; Yazdanfar and Ohman, 2016; Abobakr and Elgiziry and, 2015; Youssef and El-ghonamie, 2015; Daskalakis and Psillaki, 2009). They attributed that positive relationship mainly to low transaction and information cost and low default risk of sized firms. Additionally, they articulated that the large firms are more likely to diversify its business which decreases the probability of bankruptcy.

\subsubsection{Profitability and Leverage Ratio}

We strongly accept the hypothesis number 3, which states that: The Profitability has a significant negative relationship with the capital structure of the firm expressed by leverage ratio. The profitability is found to be negatively correlated with all leverage ratios in both samples. The negative relationship is the most prominent evidence that the Egyptian SMEs are following the pecking order theory as evidenced by the previous SMEs literature (Daskalakis et al., 2014; Cassar and Holmes 2003; Sogorb-Mira, 2005, Daskalakis and Psillaki, 2008). Conversely, Abobakr and Elgiziry (2015) showed a positive relationship between the profitability and leverage ratio which indicates that the large listed Egyptian firms are following the tradeoff theory.

\subsubsection{Liquidity and Leverage Ratio}

We partially accept the hypothesis number 4 , which states that: The liquidity has a significant negative relationship with the capital structure of the firm expressed by leverage ratio. The regression results show a perfect consistency among the SMEs of the quoted and unquoted samples, regarding the results of the impact of liquidity on leverage ratios. The liquidity had significant negative correlations with the total and short term leverage at the level of .01, while it shows insignificant neutral correlation with the long term leverage in both samples (the B values of relationships in both samples are 0). Shahadan and Saarani (2013) presented similar conclusion when they tested the capital structure determinants of SMEs in Malaysia. Also, Krasauskaite and Hirth (2011) gave a support to the pecking order hypothesis and verified the negative correlation between the two variables. Also, this negative correlation is confirmed in the Egyptian large listed companies by Omran and Pointon (2009).

\subsubsection{Growth and Leverage Ratio}

The hypothesis number 5 , which states that: The growth of the firm has a significant positive relationship with the capital structure of the firm expressed by leverage ratio, is completely rejected for the first sample and partially accepted for the second sample. The growth was insignificant to all types of leverage in the first sample. Meanwhile, it was positively significant with total leverage and short term leverage of the second sample and insignificant with the long term leverage. The results of the second sample are consistent with results of Aybar-Arias et al. (2012), Hall et al., (2000), Omran and Pointon (2009) and the assumption of Myers and Majluf (1984), who concluded that the growing companies would need outside finance.

\subsubsection{Age and Leverage Ratio}

The hypothesis number 6 , which states that: The firm's age has a significant relationship with the capital structure of the firm expressed by leverage ratio, is rejected for the total and long term leverage and is accepted only for short term leverage. The results of the regression showed that the age of the firm was significantly positive with the short term leverage, while it was insignificant with total and long term leverage. The results of the study are consistent with results of SMEs in Australia and Portugal as reported by Romano et al. (2000) and Vieira (2014) respectively.

\subsubsection{Ownership Structure and Leverage Ratio}

The hypothesis number 7, which states that: The ownership of the management and the ownership of the block shareholders have significant relationships with the leverage ratio, is not fully supported. The regression results showed that the block holding ownership had significant positive relationships only with total leverage and short 
term leverage at the level of .05. Meanwhile, it had an insignificant positive relationship with long term leverage. The results of the study are consistent with the results of previous studies such as Bajaj et al. (1998), Cheng et al. (2004), who indicated that the leverage increases as long as the ownership concentration increases. Also, Pindado and de la Torre (2005) suggested that ownership concentration encourages debt financing. The second part of the hypothesis is also accepted partially, as the managerial ownership had a significant negative association only with the short term leverage, while it had insignificant relationships with the other two dependent variables. The relationship between short term leverage and managerial ownership is entirely consistent with the previous literature, which assumed that the relationship between the two variables is shaping an inverse U-shape relationship. That means, the relationship is used to be positive to a certain limit till the management is enriched, and then the two variables will be negatively correlated. Therefore, the relationship in this research is assumed to be negative, as the average managerial ownership is quite high, of $57.1 \%$. The said relationship is evidenced by Hewa Wellalage and Locke (2015). Similar results introduced by Ang et al. (2000) and Brailsford et al. (2002), who evidenced the same U-shape results.

\subsubsection{Main Hypotheses}

All of the independent variables had a significant impact on at least one of the leverage ratios, so we accept the main hypothesis number 8. The eighth hypothesis stated that: The independent variables, Size, Liquidity, Profitability, Tangibility, Growth, Age, and Ownership structure collectively, have a significant impact on the firm's capital structure of the two samples. Also, we confirm the said hypothesis according to the results showed in table 7 , independent variables have a significant collective impact on dependent variables, and they explain $62 \%, 50.7 \%$, and $63 \%$ of the total leverage, long term leverage, and short term leverage variations respectively in the quoted sample. Similarly, results shown in table 8 proved the hypothesis, the independent variables explain $49 \%, 19.7 \%$, and $48.2 \%$ of the total leverage, long term leverage, and short term leverage variations respectively of the unquoted sample. Also, the significance of $\mathrm{F}$ for all six models is 0.000 which indicated that the independent variables together are valid to explain and predict the dependent variables significantly.

We accepted the hypothesis number 9 which states that: SMEs in Egypt are employing short term debt more than long term debt. The results of both samples of quoted and unquoted SMEs revealed a similar short term leverage ratios of $28.8 \%$ and $28.1 \%$ respectively, which contribute to $75 \%$ and $89 \%$ of total leverage of the quoted and unquoted SMEs respectively. That high contribution of short term leverage is evidenced in previous literature such as Nguyen and Ramachandran (2006), Shahadan and Saarani (2013), and Hall et al. (2004). Most of the tested variables in the two samples showed very similar results. Consequently, we partially accept the hypotheses number 10 which states that: The relationship between the capital structure determinants and leverage ratio have a similar direction across the two samples of quoted and unquoted SMEs. There are four variables out of five: asset structure, size, profitability, and liquidity, which tested in the second sample were significant in both of the two samples with the same direction of the relationship, either positive or negative. Even though, the growth was significant with the total and short term leverage only in the second sample, but it has the same positive relationship with the total leverage in both samples. The said similar results may be attributed to using the same selection and classification criteria. Also, the impact of listing on the capital structure of the first sample is still minor, because most of these firms were listed recently, which evidenced through the high ownership of the management and block holders. These results are contradicting the results introduced by SCHOUBBEN and VAN HULLE (2004). The final hypothesis is accepted, which stated that: The pecking order theory is better explaining the capital structure of SMEs. The resulted negative correlations between the leverage and the profitability \& liquidity, besides the positive correlation with the growth, are supporting the pecking order hypothesis. The study results are consistent with the previous studies which confirmed the relevance of pecking order theory to SMEs (Degryse et al., 2009; Michaelas et al., 1999; Daskalakis and Psillaki, 2008; Sogorb Mira, 2005; Hall et al., 2004; Gregory et al., 2005; Johnsen and McMahon, 2005; and Mac an Bhaird and Lucey, 2010).

\subsubsection{Control Variable}

The results of regression analysis evidenced the significant impact of the sector on the leverage ratios, as more than one sector showed a significant relationship with the leverage ratios. The significance and direction of the relationship are varied amongst the different sectors in each sample. Similar results introduced earlier by Degryse et al. (2009). Also, Omran and Pointon (2009) presented evidence for the industry effect on the capital structure of Egyptian listed companies in Egyptian stock. 


\section{Conclusion}

The study introduced descriptive analysis, Pearson correlation and regression analysis for 123 SMEs, subdivided into two samples. The first sample represents the quoted SMEs in Egypt, which is comprised of 28 listed and traded SMEs. The second sample represents the unquoted SMEs, comprised of 95 firms.

The descriptive analysis revealed that the leverage ratios are quite similar in both samples, and also, it indicated that the SMEs in Egypt are mainly using short term debt to finance their assets. The average short term leverage in the quoted and unquoted sample reached $28.8 \%$ and $28.1 \%$ respectively out of total leverage of $38.2 \%$ and $31.4 \%$ respectively. The regression analysis revealed that the independent variables, alongside with the control variable, impact the leverage ratios significantly and could explain $62.3 \%, 50.7 \%$, and $63.4 \%$ of the total leverage, long term leverage, and short term leverage of the first sample respectively. The results indicated that the applied regression models could explain and predict the behavior of $49 \%, 19.7 \%$, and $48.2 \%$ of the total leverage, long term leverage, and short term leverage of the unquoted sample respectively. Regression analysis revealed that the firm size showed positive correlations with the three leverage ratios in both samples, while the growth had only significant positive correlations with total and short term leverage of the unquoted sample. Conversely, asset structure, profitability and liquidity had significant negative correlations with all leverage ratios in the two samples, except that asset structure and liquidity depicted an insignificant correlation with long term leverage in the two samples. Accordingly, the results of the two samples show a high degree of similarities. The age displayed a significant positive relationship only with the short term leverage. Regarding the impact of ownership structure, the managerial ownership is found to be negatively correlated to short term leverage, while the block holding ownership was positively correlated to total and short term leverage. Moreover, the sector showed a significant relationship with leverage. Additionally, the results of the study demonstrate that the pecking order theory introduces the best explanation of the SMEs' financing behavior in Egypt.

\section{Contribution of the Study}

The study develops a theoretical framework to help the Egyptian policy makers and SMEs' management to understand better the factors that impact the capital structure. That understanding will help SMEs to diversify the sources of funds and to reduce the cost of capital in order to optimize the capital structure. Consequently, this optimization will maximize the investors' wealth which will substantially enhance the national economy. Also, the study enhances the available limited SME literature in emerging markets. As far as the researchers know, this is the first study that combines the results of two samples (quoted and unquoted samples) to obtain more reliable evidence about the factors affecting capital structure of SMEs in Egypt. Furthermore, the study introduces comprehensive research about SMEs in Egypt, testing a broad range of variables. The study is not only testing the impact of traditional firm characteristics but also is testing the impact of ownership structure and sector on capital structure.

\section{Limitation of the Study}

The study has some limitations such as

- $\quad$ The first sample covers the available data of listed SMEs from their first year of trading until 2015, so it does not include any financial data beyond the first year of listing and trading.

- The second sample does not include all the financial data during the full covered period and does not include the data of ownership structure and age of the firms.

\section{Implication for Policy Makers}

The policy makers in Egypt should develop a more comprehensive conceptual framework to enhance the availability of finance for small and medium enterprises. According to Berger and Udell (2006), there is a causal chain linking the availability of different kinds of SMEs' finance and the governmental policies \& financial structures. This chain starts with the governmental policies which impact the financial institution structure and lending infrastructure. Therefore, the Egyptian policy makers should consider improving the lending infrastructure including legal, tax, judicial, bankruptcy, information and regulatory environments to enhance the SMEs. Moreover, the policy makers should support the SMEs to be able to compete with large and state-owned firms.

The following are some recommendations inferred from the study results:

- Introduce innovative and tailored lending tools to SMEs (which are not based on asset or personal collateral) such as interest free community finance and Islamic finance instruments: cost-plus financing (murabaha), 
profit-sharing (mudaraba), leasing (ijara), and partnership (musharaka) which may meet the needs of some of SMEs' owners.

- The government and all SMEs concerned parties should develop a more comprehensive database for SMEs, similar to those used in other countries. This will enhance SMEs' research and will subsequently help to bridge the knowledge gap.

- Facilitate the rules and requirements, including fees of listing SMEs in NILEX, in order to secure a more sustainable long-term finance plan.

- Impose a more restricted governance system to increase the effectiveness of the role of the independent board members to reduce the managerial ownership.

- Support the international and local SME funds which supply SMEs with finance, experience, technology, and access to new markets.

- Introduce tax incentives to SMEs and facilitate the tax reporting requirements.

- The government should consider the specialty and dynamic nature while developing mechanisms for supporting SMEs.

\section{References}

Abor, J. (2008). Agency theoretic determinants of debt levels: evidence from Ghana. Review of Accounting and finance, 7(2), 183-192. https://doi.org/10.1108/14757700810874146

Anderson, R. C., \& Reeb, D. M. (2003). Founding-family ownership, corporate diversification, and firm leverage. The Journal of Law and Economics, 46(2), 653-684. https://doi.org/10.1086/377115

Ang, J. S., Cole, R. A., \& Lin, J. W. (2000). Agency costs and ownership structure. The Journal of Finance, 55(1), 81-106. https://doi.org/10.1111/0022-1082.00201

Abobakr, M. G., and Elgiziry, K. (2015). The Effects of Board Characteristics and Ownership Structure on the Corporate Financial Leverage. Accounting and Finance Research, 5(1), 1. https://doi.org/10.5430/afr.v5n1p1

Aybar-Arias, C., Casino-Martínez, A., \& López-Gracia, J. (2012). On the adjustment speed of SMEs to their optimal capital structure. Small business economics, 39(4), 977-996. https://doi.org/10.1007/s11187-011-9327-6

Balakrishnan, S., \& Fox, I. (1993). Asset specificity, firm heterogeneity and capital structure. Strategic Management Journal, 14(1), 3-16. https://doi.org/10.1002/smj.4250140103

Bajaj, M., Chan, Y. S., \& Dasgupta, S. (1998). The relationship between ownership, financing decisions and firm performance: A signaling model. International Economic Review, 723-744. https://doi.org/10.2307/2527397

Bhaird, C. and Lucey, B. (2010), "Determinants of capital structure in Irish SMEs", Small Business Economics, 35(3), 357-375. https://doi.org/10.1007/s11187-008-9162-6

Benkraiem, R., \& Gurau, C. (2013). How do corporate characteristics affect capital structure decisions of French SMEs? International Journal of Entrepreneurial Behavior \& Research, 19(2), 149-164. https://doi.org/10.1108/13552551311310356

Berger, A. N., \& Udell, G. F. (1998). The economics of small business finance: The roles of private equity and debt markets in the financial growth cycle. Journal of banking \& finance, 22(6), 613-673. https://doi.org/10.1016/S0378-4266(98)00038-7

Berger, A. N., Saunders, A., Scalise, J. M., \& Udell, G. F. (1998). The effects of bank mergers and acquisitions on small business lending. Journal of financial Economics, 50(2), 187-229. https://doi.org/10.1016/S0304-405X(98)00036-1

Berger, A. N., \& Udell, G. F. (2006). A more complete conceptual framework for SME finance. Journal of Banking and Finance, 11(30), 2945-2966. https://doi.org/10.1016/j.jbankfin.2006.05.008

Bokpin, G. A., \& Arko, A. C. (2009). Ownership structure, corporate governance and capital structure decisions of firms: Empirical evidence from Ghana. Studies in Economics and Finance, 26(4), 246-256. https://doi.org/10.1108/10867370910995708

Brailsford, T. J., Oliver, B. R., \& Pua, S. L. (2002). On the relation between ownership structure and capital structure. Accounting \& Finance, 42(1), 1-26. https://doi.org/10.1111/1467-629X.00001 
Cassar, G., and Holmes, S. (2003). Capital structure and financing of SMEs: Australian evidence. Accounting and Finance, 43(2), 123-147. https://doi.org/10.1111/1467-629X.t01-1-00085

Central Bank of Egypt (CBE) and Egyptian Banking Institute. (2012). Innovations in SME Financing. Available online at http://www.ebrd.com/downloads/news/sme_census.pdf

CBE website. http://www.cbe.org.eg/en/Pages/default.aspx

Cheng, S., Nagar, V., \& Rajan, M. V. (2004). Identifying control motives in managerial ownership: Evidence from antitakeover legislation. The Review of Financial Studies, 18(2), 637-672. https://doi.org/10.1093/rfs/hhh010

Daskalakis, N., Eriotis, N., Thanou, E., \& Vasiliou, D. (2014). Capital structure and size: new evidence across the broad spectrum of SMEs. Managerial Finance, 40(12), 1207-1222. https://doi.org/10.1108/MF-11-2013-0325

Daskalakis, N., \& Psillaki, M. (2008). Do country or firm factors explain capital structure? Evidence from SMEs in France and Greece. Applied financial economics, 18(2), 87-97. http://dx.doi.org/10.1080/09603100601018864

Degryse, H., de Goeij, P., \& Kappert, P. (2012). The impact of firm and industry characteristics on small firms' capital structure. Small Business Economics, 38(4), 431-447. https://doi.org/10.1007/s11187-010-9281-8

Degryse, H., De Goeij, P., \& Kappert, P. (2009). The impact of firm and industry characteristics on small firms' capital structure: Evidence from Dutch panel data. http://dx.doi.org/10.2139/ssrn.1361498

Driffield, N., Mahambare, V., \& Pal, S. (2005). How ownership structure affects capital structure and firm performance? Recent evidence from East Asia. Finance 0505010, Economics Working Paper.

EL-Ansary, U. (2008). Determinants of the Capital Structure of Egyptian Corporations. The Review of the Faculty of Commerce, Banha University, No., 2, 2008.

El-Said, H., Al-Said, M., \& Zaki, C. (2014). Small and medium enterprises landscape in Egypt: New facts from a new dataset. Journal of Business and Economics, ISSN 2155-7950, USA February 2014, Volume 5, No. 2, pp. 142-161 .Academic Star Publishing Company. http://www.academicstar.us

Forte, D., Barros, L. A., \& Nakamura, W. T. (2013). Determinants of the capital structure of small and medium sized Brazilian enterprises. BAR-Brazilian Administration Review, 10(3), 347-369. http://dx.doi.org/10.1590/S1807-76922013000300007

Friend, I., \& Lang, L. H. (1988). An empirical test of the impact of managerial self-interest on corporate capital structure. The Journal of Finance, 43(2), 271-281. https://doi.org/10.1111/j.1540-6261.1988.tb03938.x

Gregory, B. T., Rutherford, M. W., Oswald, S., \& Gardiner, L. (2005). An empirical investigation of the growth cycle theory of small firm financing. Journal of Small Business Management, 43(4), 382-392. https://doi.org/10.1111/j.1540-627X.2005.00143.x

Hall, G., Hutchinson, P., \& Michaelas, N. (2000). Industry effects on the determinants of unquoted SMEs' capital structure. International journal of the economics of business, 7(3), 297-312. http://dx.doi.org/10.1080/13571510050197203

Hall, G. C., Hutchinson, P. J., \& Michaelas, N. (2004). Determinants of the capital structures of European SMEs. Journal of Business Finance \& Accounting, 31(5-6), $\quad$ 711-728. https://doi.org/10.1111/j.0306-686X.2004.00554.X

Holmes, S., \& Kent, P. (1991). An empirical analysis of the financial structure of small and large Australian manufacturing enterprises. The Journal of Entrepreneurial Finance, 1(2), 141. http://hdl.handle.net/10419/114633

Huang, W., Boateng, A., \& Newman, A. (2016). Research Online@ GCU. Small Bus Econ, 47, 535-550. https://link.springer.com/article/10.1007/s11187-016-9729-6

Hewa Wellalage, N., \& Locke, S. (2015). Impact of ownership structure on capital structure of New Zealand unlisted firms. Journal of Small Business and Enterprise Development, 22(1), 127-142. https://doi.org/10.1108/JSBED-09-2011-0004

Hair, J. F., Black, W. C., Babin, B. J., Anderson, R. E., and Tatham, R. L., (2006). Multivariate Data Analysis, 6th edition, New Jersy, Person Prentice Hall. 
Krasauskaite, E., and Hirth, S. (2011). Capital Structure of SMEs: Does Firm Size Matter. Empirical investigation of the Baltic countries. Masters study, Aarhus University.http://pure.au.dk/portal/files/40429737/Capital_Structure_of_SMEs_Does_Firm_Size_Matter.pdf

Lucey, B. M., \& Mac an Bhaird, C. (2006). Capital structure and the financing of SMEs: Empirical evidence from an Irish survey. Electronic copy available at: http://ssrn.com/abstract=905845. http://dx.doi.org/10.2139/ssrn.905845

Mac an Bhaird, C. (2010). The Modigliani-Miller proposition after fifty years and its relation to entrepreneurial finance. Strategic Change, 19(1 - 2), 9-28. https://doi.org/10.1002/jsc.855

Mac an Bhaird, C., \& Lucey, B. (2010). Determinants of capital structure in Irish SMEs. Small business economics, 35(3), 357-375. https://doi.org/10.1007/s11187-008-9162-6

Mac an Bhaird, C., \& Lucey, B. (2011). An empirical investigation of the financial growth lifecycle. Journal of Small Business and Enterprise Development, 18(4), 715-731. https://doi.org/10.1108/14626001111179767

Mateev, M., Poutziouris, P., \& Ivanov, K. (2013). On the determinants of SME capital structure in Central and Eastern Europe: A dynamic panel analysis. Research in International Business and Finance, 27(1), 28-51. https://doi.org/10.1016/j.ribaf.2012.05.002

Michaelas, N., Chittenden, F., \& Poutziouris, P. (1999). Financial policy and capital structure choice in UK SMEs: Empirical evidence from company panel data. Small business economics, 12(2), 113-130. https://doi.org/10.1023/A:1008010724051

Modigliani, F., \& Miller, M. H. (1958). The cost of capital, corporation finance and the theory of investment. The American economic review, 48(3), 261-297. Published by: American Economic Association . http://www.jstor.org/stable/1809766

Modigliani, F., \& Miller, M. H. (1963). Corporate income taxes and the cost of capital: a correction. The American economic review, 433-443. Published by: American Economic Association. http://www.jstor.org/stable/1809167

Myers, S. C., \& Majluf, N. S. (1984). Corporate financing and investment decisions when firms have information that investors do not have. Journal of financial economics, 13(2), 187-221. https://doi.org/10.1016/0304-405X(84)90023-0

Myers, S. C. (2001). Capital structure. The journal of economic perspectives, 15(2), 81-102. https://doi.org/10.1257/jep.15.2.81

Newman, A., Borgia, D., \& Deng, Z. (2013). How Do SMEs with Single and Multiple Owners Finance Their Operations Differently? Empirical Evidence from China. Thunderbird International Business Review, 55(5), 531-544. https://doi.org/10.1002/tie.21568

Nguyen, T. D. K., \& Ramachandran, N. (2006). Capital structure in small and medium-sized enterprises: the case of Vietnam. ASEAN Economic bulletin, 23(2), 192-211. https://doi.org/10.1355/AE23-2D

NILEX website: http://www.nilex.com.eg/en/

Organization for Economic Co-operation and Development (OECD) (2006), The SME Financing Gap Theory and Evidence Volume I, Organization for Economic Co-operation and Development, Paris. http://dx.doi.org/10.1787/9789264029415-en

Omran, M. M., \& Pointon, J. (2009). Capital structure and firm characteristics: an empirical analysis from Egypt. Review of Accounting and Finance, 8(4), 454-474. https://doi.org/10.1108/14757700911006976

Pettit, R. R., \& Singer, R. F. (1985). Small business finance: a research agenda. Financial management, 47-60. Published by: Wiley on behalf of the Financial Management Association International. http://www.jstor.org/stable/3665059

Pindado, J., \& de la Torre, C. (2005). A complementary approach to the financial and strategy views of capital structure: theory and evidence from the ownership structure. Working Paper No. 666167, Social Science Research Network. http://dx.doi.org/10.2139/ssrn.666167

Psillaki, M., \& Daskalakis, N. (2009). Are the determinants of capital structure country or firm specific? Small Business Economics, 33(3), 319-333. https://doi.org/10.1007/s11187-008-9103-4 
Radwan, S., \&Walie, L., (2008). Small and Medium Investment (SMI) A window of opportunity for Egypt. General Authority for Investment.

Rajan, R. G., \& Zingales, L. (1995). What do we know about capital structure? Some evidence from international data. The journal of Finance, 50(5), 1421-1460. https://doi.org/10.1111/j.1540-6261.1995.tb05184.x

Romano, C. A., Tanewski, G. A., \& Smyrnios, K. X. (2001). Capital structure decision making: A model for family business. Journal of business venturing, 16(3), 285-310. https://doi.org/10.1016/S0883-9026(99)00053-1

Sánchez-Vidal, J., \& Martín-Ugedo, J. F. (2012). Are the implications of the financial growth cycle confirmed for Spanish SMEs? Journal of Business Economics and Management, 13(4), 637-665. http://dx.doi.org/10.3846/16111699.2011.620161

Schoubben, F., \& Van Hulle, C. (2004). The Determinants of Leverage: Differences between Quoted and Unquoted Firms. Tijdschrift voor Economie en Management, 49(4), 589-622. https://lirias.kuleuven.be/bitstream/123456789/274828/2

Saarani, A. N., \& Shahadan, F. (2013). The determinant of capital structure of SMEs in Malaysia: Evidence from enterprise 50 (e50) SMEs. Asian Social Science, 9(6), 64. http://dx.doi.org/10.5539/ass.v9n6p64

Saarani, A. N., \& Shahadan, F. (2013). The comparison of capital structure determinants between Small And Medium Enterprises (SMEs) and large firms in Malaysia. International Journal of Economics and Finance Studies, 5(1), 64-73

Sogorb-Mira, F. (2005). How SME uniqueness affects capital structure: Evidence from a 1994-1998 Spanish data panel. Small business economics, 25(5), 447-457. https://doi.org/10.1007/s11187-004-6486-8

Thornhill, S., Gellatly, G., \& Riding, A. (2004). Growth history, knowledge intensity and capital structure in small firms. Venture Capital, 6(1), 73-89. http://dx.doi.org/10.1080/1369106042000175591

Tian, L., Han, L., \& Zhang, S. (2015). Business life cycle and capital structure: evidence from Chinese manufacturing firms. China \& World Economy, 23(2), 22-39. https://doi.org/10.1111/cwe.12105

Vieira, E. S. (2014). Capital structure determinants in the context of listed family firms. Journal of Economy, Business and Financing, 2(1), 12-25. https://www.researchgate.net/publication/260436750

Yazdanfar, D., Yazdanfar, D., Öhman, P., \& Öhman, P. (2016). Capital structure dynamics among SMEs: Swedish empirical evidence. The Journal of Risk Finance, 17(2), 245-260. https://doi.org/10.1108/JRF-04-2015-0040

Youssef, A., \& El-Ghonamie, A. (2015). Factors That Determine Capital Structure in Building Material and Construction Listed Firms: Egypt Case. International Journal of Financial Research,6(4), 46. https://doi.org/10.5430/ijfr.v6n4p46

Zhang, Y. (2010). The product category effects on capital structure: evidence from the SMEs of British manufacturing industry. International Journal of Business and Management, 5(8), 86. Published by Canadian Center of Science and Education. ISSN 1833-3850 E-ISSN 1833-8119. https://doi.org/10.5539/ijbm.v5n8p86 